\title{
Iron oxide Nanoparticales role in micropropagation of Moringa oleifera L. under salinity stress
}

\section{Iman M. El-Sayed, Lobna S. Taha, Azza M.A. Mazhar and Magda M. Kandil}

Department of Ornamental Plants and Woody Trees, Agricultural and Biological Research Division, National Research Centre (NRC), 33 El-Buhouth St., 12622 Dokki, Giza, Egypt

Received: 10 Sept. 2019 / Accepted 30 Oct. 2019 / Publication date: 10 Nov. 2019

\begin{abstract}
Micropropagation is the most important tool to propagate some important economic trees such as Moringa oleifera L. to examine the morphological reaction of in vitro grown plantlets on MS culture medium supplemented with different PGR (BA, IBA, NAA and Kinetin) and investigate the in vitro propagation ability under $\mathrm{NaCl}$ different concentrations $(0,1,2,4$ and $8 \mathrm{~g} / \mathrm{l})$. Adding two levels of Iron Oxide NPs $(5$ and $10 \mathrm{mg} / \mathrm{L}$ ) was used to mitigate the effect of salt stress on micropropagation of plants. The results showed that $\mathrm{NaCl}$ at different concentrations significantly reduced the in vitro recorded shoots and roots parameters (number of shootlets, shootlet length, rooting \%, number and length of roots), chlorophyll content and carotenoids. Moreover, proline content was increased with increasing $\mathrm{NaCl}$ concentration in the culture medium. In addition, adding Iron Oxide NPs to culture medium showed positive effects on alleviating salt stress. This study aimed to evaluate the adverse effect of salt stress on Moringa oleifera L. micropropagation and the possibility of using Iron oxide NPs to overcome these effects.
\end{abstract}

Keywords: Moringa oleifera L., micropropagation, salinity, Iron oxide NPs.

\section{Introduction}

The widely cultivated Moringa oleiferab in tropical and subtropical regions of the world is a fast- growing deciduous tree and known for its multipurpose such as a source of food, shelter and traditional medicine especially in developing countries. Several studies have been conducted to assess the various claims of traditional medicine practitioners that Moringa tree can improve health and cure various diseases. The tree has a high nutritional profile, especially nutrient-rich leaves. Some reports also support the use of tree parts to reduce blood sugar and cholesterol levels. These attractive characteristics have led researchers to seek new uses of the Moringa tree, especially as a source of anti-cancer drugs. Researchers have tested extracts from different parts of the Moringa tree in vitro and in vivo on several types of cancers with varying success (Khor et al., 2018). The plant is also known as a Horse- radish tree, Drumstick tree. Each part of this plant has a valuable medical advantage. It contains a rich source of vitamin A, vitamin C and milk protein (Birendra et al., 2017). Moringa oleifera is traditionally propagated by seeds. Plants obtained from seeds vary in genotype and phenotype thus leading to variations in the quality of the yield. Therefore, propagation of elite genotype can be propagated via micropropagation techniques. In general, explant type, culture conditions and plant growth regulator regimes must be defined for each genotype in order to develop the successful micropropagation protocol (Stephenson and Fahey, 2004; Marfori, 2010 and Saini et al., 2012)

Application of saline water in agriculture requires deep understanding of law to overcome the negative effects of salinity. Tissue culture technique supplements with artificial tools to study the effect of salinity on plants under conditions and production of the range of plant species all over the world (Gayathri et al., 2015).

Trace iron is an important and necessary ingredient for all living organisms. Iron is an essential element in cell metabolism and is involved in photosynthesis, respiration, etc (Rashno et al., 2013). The nanoparticles of iron oxide are smaller than typical iron particles and create more complexes with higher iron availability for plants (Mazaherinia et al., 2010).

Corresponding Author: Iman M. El-Sayed, Department of Ornamental Plants and Woody Trees, Agricultural and Biological Research Division, National Research Centre (NRC), Egypt.

E-mail: imanelsayed6065@yahoo.com 
The aim of the present investigation was to optimum micropropagation ability of Moringa oleifera under saline condition and study the possibility of using Iron oxide NPs to mitigate these effects.

\section{Materials and Methods}

These investigations were conducted at Tissue Culture Technique Lab., Central laboratories, Department of Ornamental Plants and Woody Trees, National Research Centre (NRC), during years 2018-2019 to evaluate some morphological, chemical changes of Moringa oleifera plants cultured in vitro under the effect of salt stress.

\section{Explant source and surface sterilization}

Seeds of Moringa oleifera were collected from nursery of Timber Trees Department Horticulture Research Institute- Agriculture Research Centre, Giza, Egypt. The seeds were washed and sterilized in ethanol $70 \%(\mathrm{v} / \mathrm{v})$ for 30 seconds then immersed in $15 \%$ of sodium hypochlorite (Clorox) for 7 minutes then $1 \%$ of $\mathrm{HgC}_{12}(\mathrm{MC})$ solution (w/v) for 10 minutes and rinsed three times in sterile water.

\section{Culture medium}

After surface sterilization, seeds of Moringa oleifera were cultured for one month on MS free of hormones (Murashige and Skoog, 1962). The obtained seedlings were subcultured on MS medium supplemented with $0.2 \mathrm{ppm}$ of 6 - benzylamino-purine (BAP) and $0.1 \mathrm{ppm}$ indole butyric acid (IBA), $2.5 \%$ sucrose and $0.7 \%$ agar. The $\mathrm{pH}$ of the medium was adjusted to $5.6-5.8$ then autoclaved at $121^{\circ} \mathrm{C}$ and 15 psi for 15 minutes. The in vitro obtained shootlets were used as explant source for testing the morphogenetic reaction on MS medium supplemented with three PGR: IBA (indole-3-butyric acid), BAP (benzyl amino purine), NAA ( $\alpha$-naphthaleneacetic acid) and Kinetin as in Table (1).

Table 1: PGR concentrations used for testing the in vitro morphological reaction of explants of Moringa oleifera.

\begin{tabular}{ccccc}
\hline Medium & \multicolumn{4}{c}{ Concentration of hormones $\left[\mathbf{m g} / \mathbf{l}^{-1}\right]$} \\
IBA & BA & NAA & Kinetin \\
\hline 1 & - & - & - & - \\
2 & 0.1 & 0.2 & - & - \\
3 & - & 0.1 & 0.1 & 0.2 \\
\hline
\end{tabular}

First experiment: Various concentrations $(0,1,2,4$ and $8 \mathrm{~g} / \mathrm{L})$ of $\mathrm{NaCl}$ were examined under in vitro conditions.

Second experiment: Studying the salt stress alleviation ability on the plant using two Iron oxide NPs $(5.0$ and $10 \mathrm{mg} / \mathrm{l})$ was carried out as follows:

1-Control

2-Control $+\mathrm{NaCl}(1 \mathrm{~g} / \mathrm{L})+5.0 \mathrm{mg} / \mathrm{L} \mathrm{Fe} \mathrm{NPs}$

$3-$ Control $+\mathrm{NaCl}(1 \mathrm{~g} / \mathrm{L})+10 \mathrm{mg} / \mathrm{L}$ Fe NPs

4-Control $+\mathrm{NaCl}(2 \mathrm{~g} / \mathrm{L})+5.0 \mathrm{mg} / \mathrm{L} \mathrm{Fe} \mathrm{NPs}$

5-Control $+\mathrm{NaCl}(2 \mathrm{~g} / \mathrm{L})+10 \mathrm{mg} / \mathrm{L} \mathrm{Fe} \mathrm{NPs}$

6-Control $+\mathrm{NaCl}(4 \mathrm{~g} / \mathrm{L})+5.0 \mathrm{mg} / \mathrm{L} \mathrm{Fe} \mathrm{NPs}$

7-Control $+\mathrm{NaCl}(4 \mathrm{~g} / \mathrm{L})+10 \mathrm{mg} / \mathrm{L}$ Fe NPs

8-Control $+\mathrm{NaCl}(8 \mathrm{~g} / \mathrm{L})+5.0 \mathrm{mg} / \mathrm{L} \mathrm{Fe} \mathrm{NPs}$

9-Control $+\mathrm{NaCl}(8 \mathrm{~g} / \mathrm{L})+10 \mathrm{mg} / \mathrm{L} \mathrm{Fe} \mathrm{NPs}$

\section{Culture conditions:}

Cultures were incubated in growth chamber at $24 \pm 1^{\circ} \mathrm{C}$ under white cool florescent lamps with light intensity of $3 \mathrm{k}$ lux at $16 \mathrm{hr}$ photoperiod.

The culture period for each experiment (first and second) took two months after start of culture then, the following data were recorded: 
Shooting behavior: Survival \%, number of formed shootlets per explant and shootlet length $(\mathrm{mm})$.

Rooting behavior: Percentage of roots formation (\%), number of roots/shootlet and root length (mm).

\section{Extraction and chemical analysis \\ Photosynthetic pigments}

Photosynthetic pigments (chlorophyll a and b) as well as carotenoids were determined in shootlets tissues as $\mathrm{mg} / 100 \mathrm{~g} \mathrm{~F}$.W. using spectrophotometer, according to the procedure achieved by Saric et al (1967).

\section{Proline}

The proline content in leaves (mg/g F.W.) was determined using the method described by Bates et al. (1973).

\section{Specification of used NPs in the experiment}

\section{Iron Oxide NPs}

\section{Specification test method}

\begin{tabular}{ccc}
\hline Phase & Hematite & XRD \\
\hline Particle size & $<50 \mathrm{~nm}$ & TEM \\
Surface area & $>50 \mathrm{~m}^{2} / \mathrm{gm}$ & BET (P/Po: up to 0.35 \\
\hline
\end{tabular}
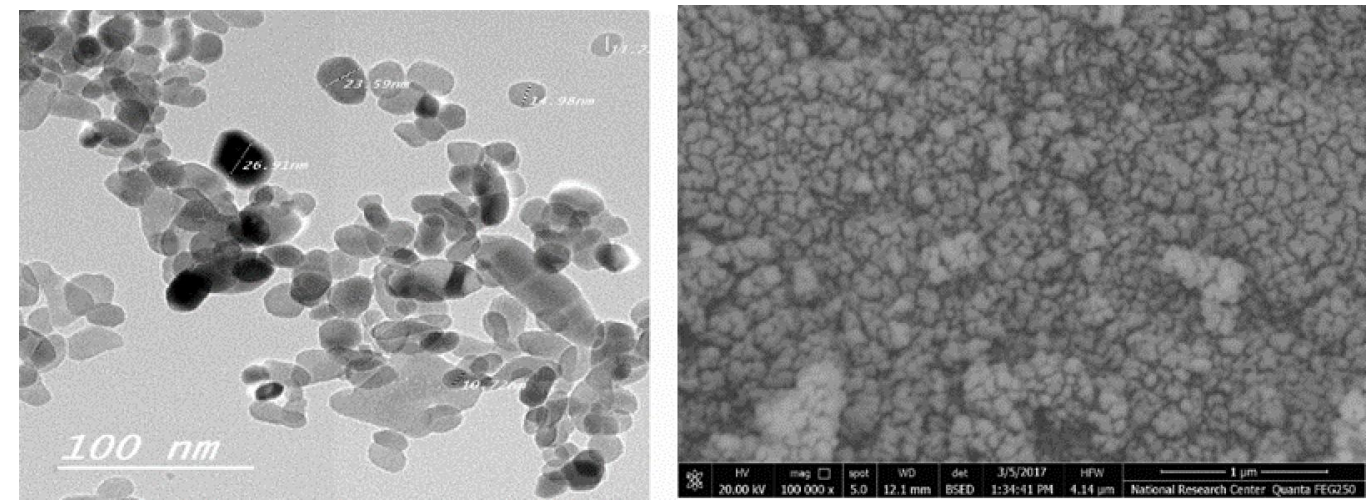

Fig. 1: Scanning electron microscopy image of Iron oxide NPs

\section{Results and Discussion}

\section{Culture establishment of Moringa oleifera under effect of growth regulators}

Data in Table (2) observed the in vitro shoot multiplication on MS culture media added with different PGR such as BA, IBA, NAA and Kinetin that were compared after nearly 8 weeks of culture. It can be seen that the highest number of shootlets $(7.30)$, longest shootlets $(48.33 \mathrm{~mm})$, highest rooting percentage $(100 \%)$, number of roots $(7.8)$ and longest roots $(51.66 \mathrm{~mm})$ per explants was observed for the culture media without any PGR compared to other culture media (MS contained BA $0.1 \mathrm{mg} / 1$ and IBA $0.1 \mathrm{mg} / 1$ or MS containing BA $0.1 \mathrm{mg} /$ kinetin $0.2 \mathrm{mg} / 1$ and NAA $0.1 \mathrm{mg} / \mathrm{l})$. In this study, data observations such as shoot multiplication and growth of shoot and root initiation were promoted by culture medium without PGR more than other treatments. Similar results were noticed by Nayak et al., (2010) on Bambusa arundinacea showed that the highest multiplication can be obtained in medium without Kin. In conclusion, type and concentration of growth regulators and species (genotype) are the most important factors in the plant Micropropagation. Few studies have shown the positive effect of without growth regulator on micropropagation of different plants. The current study showed the positive effect of MS without growth regulator, on micropropagation of Moringa oleifera. Growth regulators are significantly important for in vitro shoot proliferation, but some internal factors and nutrient conditions can modify their activities (Park et al., 2001). Moreover, endogenous levels of growth regulators in the explant showed different regeneration efficiencies (Nontaswatsri et al., 2002). 
Table 2: In vitro shooting behavior of Moringa oleifera under effect of growth regulators.

\begin{tabular}{|c|c|c|c|c|c|}
\hline Treatments & $\begin{array}{c}\text { Number of } \\
\text { shootlets/ } \\
\text { explant }\end{array}$ & $\begin{array}{c}\text { Shootlet } \\
\text { length } \\
(\mathrm{mm})\end{array}$ & $\begin{array}{c}\text { Rooting } \\
\text { (\%) }\end{array}$ & $\begin{array}{c}\text { Number } \\
\text { of roots/ } \\
\text { plantlet }\end{array}$ & $\begin{array}{c}\begin{array}{c}\text { Length } \\
\text { of roots } \\
\text { (mm) }\end{array} \\
\end{array}$ \\
\hline$\overline{M S f}$ & $7.30 \mathrm{a}$ & $48.33 a$ & & $7.8 \mathrm{a}$ & $51.66 \mathrm{a}$ \\
\hline $0.2 \mathrm{mg} / 1+\mathrm{Il}$ & $4.66 \mathrm{ab}$ & $39.33 \mathrm{a}$ & a & 7.8 & $20.00 \mathrm{~b}$ \\
\hline $\mathrm{MS}+\mathrm{BA} 0.1 \mathrm{mg} / 1+\mathrm{NAA} 0.1 \mathrm{mg} / 1+\mathrm{Kin} 0.2 \mathrm{mg} / 1$ & $3.5 \mathrm{~b}$ & $26.66 \mathrm{~b}$ & $22.2 \mathrm{~b}$ & $2.0 \mathrm{c}$ & $12.33 \mathrm{~b}$ \\
\hline
\end{tabular}

\section{2-In vitro shooting and rooting behaviors of Moringa oleifera under effect of various $\mathrm{NaCl}$} concentrations

Data in Fig. $(2,3)$ showed that control explant had highest values of all in vitro shoot parameters (number of shootlets/ explant, shootlet length, rooting percentage, number of roots and root length). The lowest $\mathrm{NaCl}$ concentration in culture medium gave the best values compared to other treatments of $\mathrm{NaCl}$.

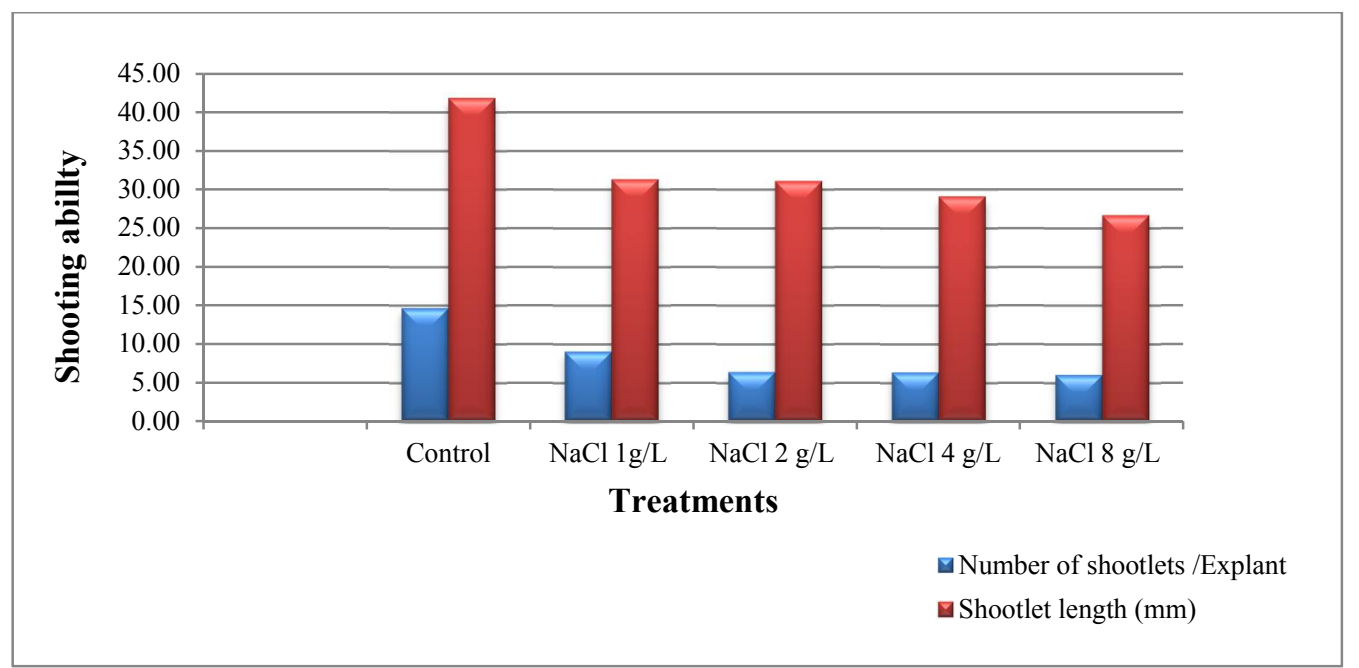

Fig. 2: In vitro shooting behaviors of Moringa oleifera under effect of various concentrations of $\mathrm{NaCl}$

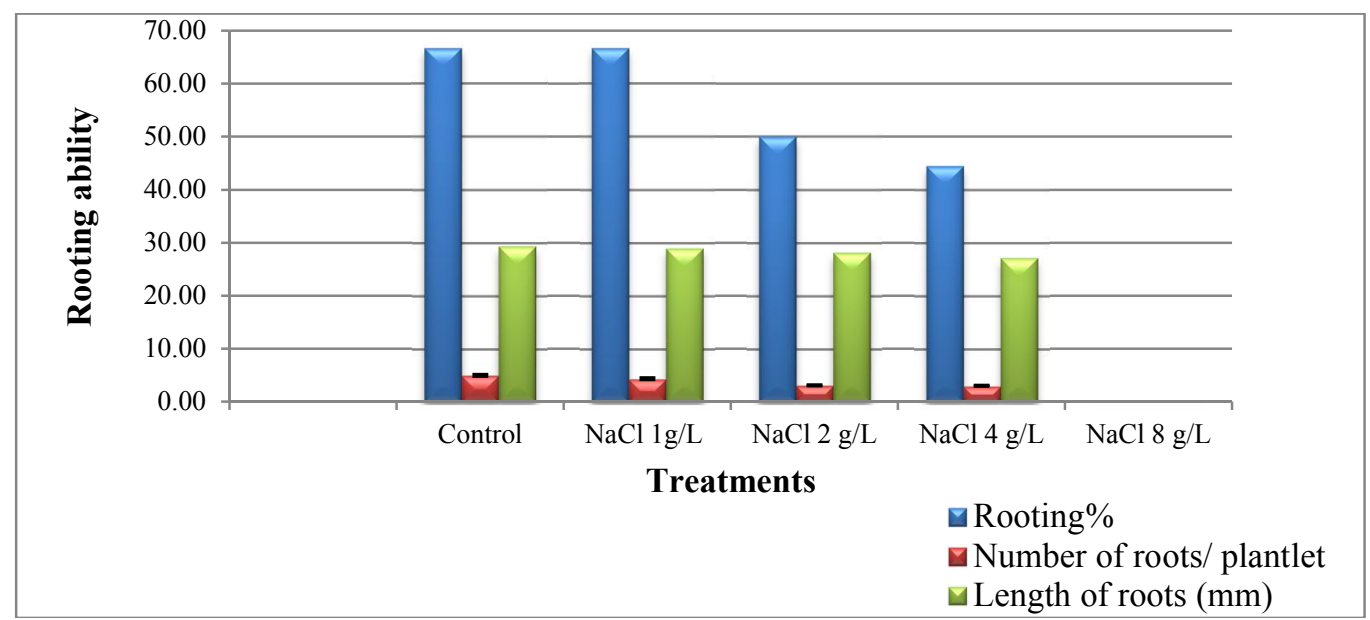

Fig. 3: In vitro rooting behaviors of Moringa oleifera under effect of various concentrations of $\mathrm{NaCl}$

Similar results were found by Soliman et al.(2012) on Acacia saligra who mentioned the reduction in the number of both leaves and branches and shoot growth as a result of salt stress.

Sayed et al. (2014) observed that Tagetes erecta L. reduction of plant height, root length, no of leaves that cultured under higher concentration of $\mathrm{NaCl}$.

Salem (2016) on Moringa oleifera observed that under salinity, retardation in shoot multiplication and growth was noticed. 
Salinity negatively affects plant growth through many physiological and biochemical methods such as toxicity, osmotic pressure, nutritional deficiencies, chemical and physiological disturbances (Kao et al., 2003).In addition, high salinity may prevent root and shoot elongation due to slow water absorption by the plant. Over time, $\mathrm{Na}+$ and $\mathrm{Cl}$ - for concentrations will accumulate in the shoot resulting in early leaf senescence and death due to the ionic component of salt (Hairmansis et al., 2014).

\section{3-Effect of $\mathrm{NaCl}$ on proline content}

Data of proline content of leaf samples that were taken from shootlets receiving different $\mathrm{NaCl}$ concentrations (Fig.4) showed that, with increasing $\mathrm{NaCl}$ in culture medium, the proline content was generally increased. Accordingly, the highest salt concentration $(4 \mathrm{~g} / \mathrm{l})$ had the highest mean proline content $(0.63 \mathrm{mg} / \mathrm{g}$ F.W.). On the other hand, control plants and those that were cultured on the lowest $\mathrm{NaCl}$ concentration had the lowest mean proline content ( 0.11 and $0.13 \mathrm{mg} / \mathrm{g} \mathrm{F}$.W., respectively).

These results agreed with Soliman et al., (2015) who mentioned the increase of proline content in leaves under different levels of salt stress on Moringa plant.

Proline serves as storage, sink for carbon and nitrogen and it is a free-radical. It also stabilizes subcellular structures (membranes and proteins), and buffers cellular redox potential. Hence, these organic osmolytes are known as osmoprotectants, these organic solutes may contribute to osmotic adjustment, protecting cell structure and function, and/or may serve as a metabolic or an energetic reserve (Chen and Murata, 2000).

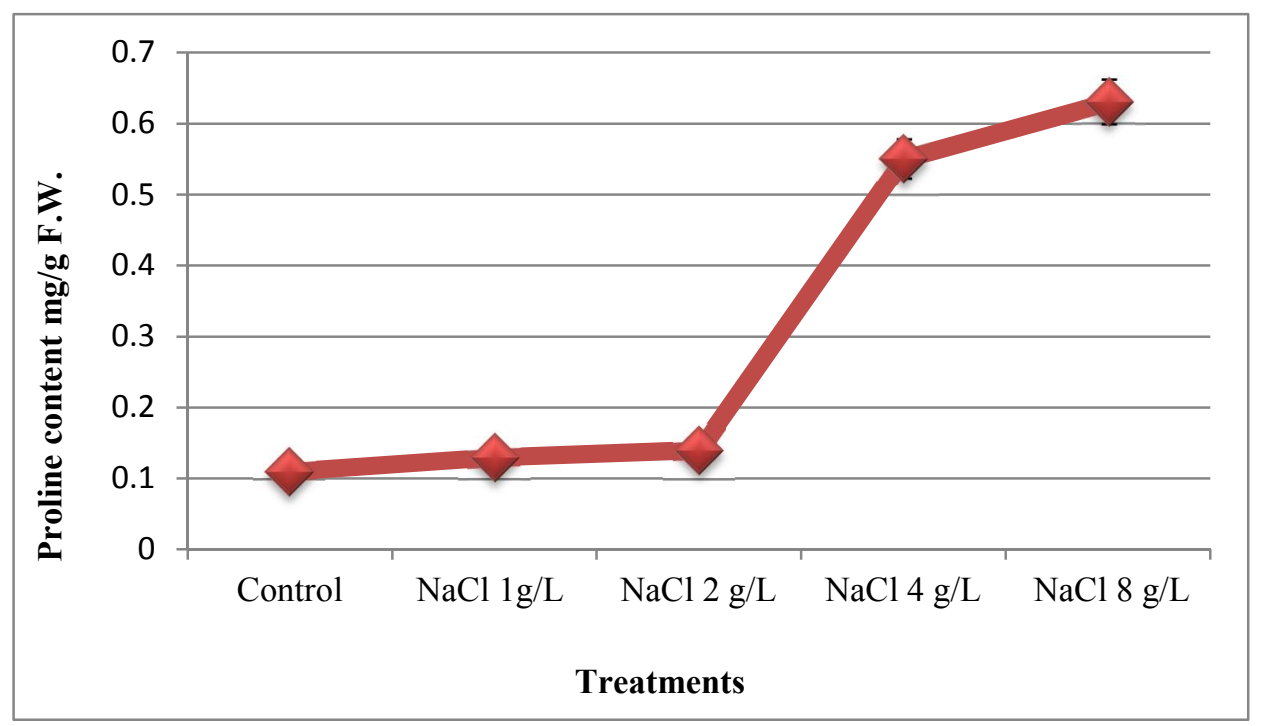

Fig. 4: Effect of various concentrations of $\mathrm{NaCl}$ levels on proline content of Moringa olifera

\section{4-Effect of salt stress on Chlorophylls $(a, b)$ and total carotenoids contents}

Fig. (5) showed that adding $\mathrm{NaCl}$ at $1 \mathrm{~g} / \mathrm{L}$ to the culture medium significantly increased chlorophyll a content to the highest value $(60.92 \mathrm{mg} / 100 \mathrm{~g}$.F.W. $)$, while using of $\mathrm{NaCl}$ at $8 \mathrm{~g} / \mathrm{L}$ declined this value to the lowest one $(13.16 \mathrm{mg} / 100 \mathrm{~g}$. F.W.) and significantly reduced Chl.a as compared to control. Decreasing the concentration of $\mathrm{NaCl}$ to $1 \mathrm{~g} /$ /in the culture medium significantly increased Chl.b as well as carotenoid contents giving the highest values with lowest concentration of $\mathrm{NaCl}$, whereas using $\mathrm{NaCl}$ at $8 \mathrm{~g} / \mathrm{L}$ significantly decreased these values as compared to control. These results were confirmed by Sayed et al., (2014) on Tagetes erecta L. who mentioned that Chlorophylls $\mathrm{a}, \mathrm{b}$ and carotenoids exhibited reduction under higher concentration of $\mathrm{NaCl}$. Soliman et al., (2015) studied that total chlorophyll $(\mathrm{a}, \mathrm{b})$ and carotenoid contents were significantly low in plants grown under salt stress condition on Morenga oleifera plant. The accumulated amount of ions enter the plant through the transpiration stream, thereby causing cells injury in the transpiring leaves which may cause further reductions in photosynthesis processes thereby leading to growth reduction (El-Fouly et al., 2002; Munns et al., 2006) 

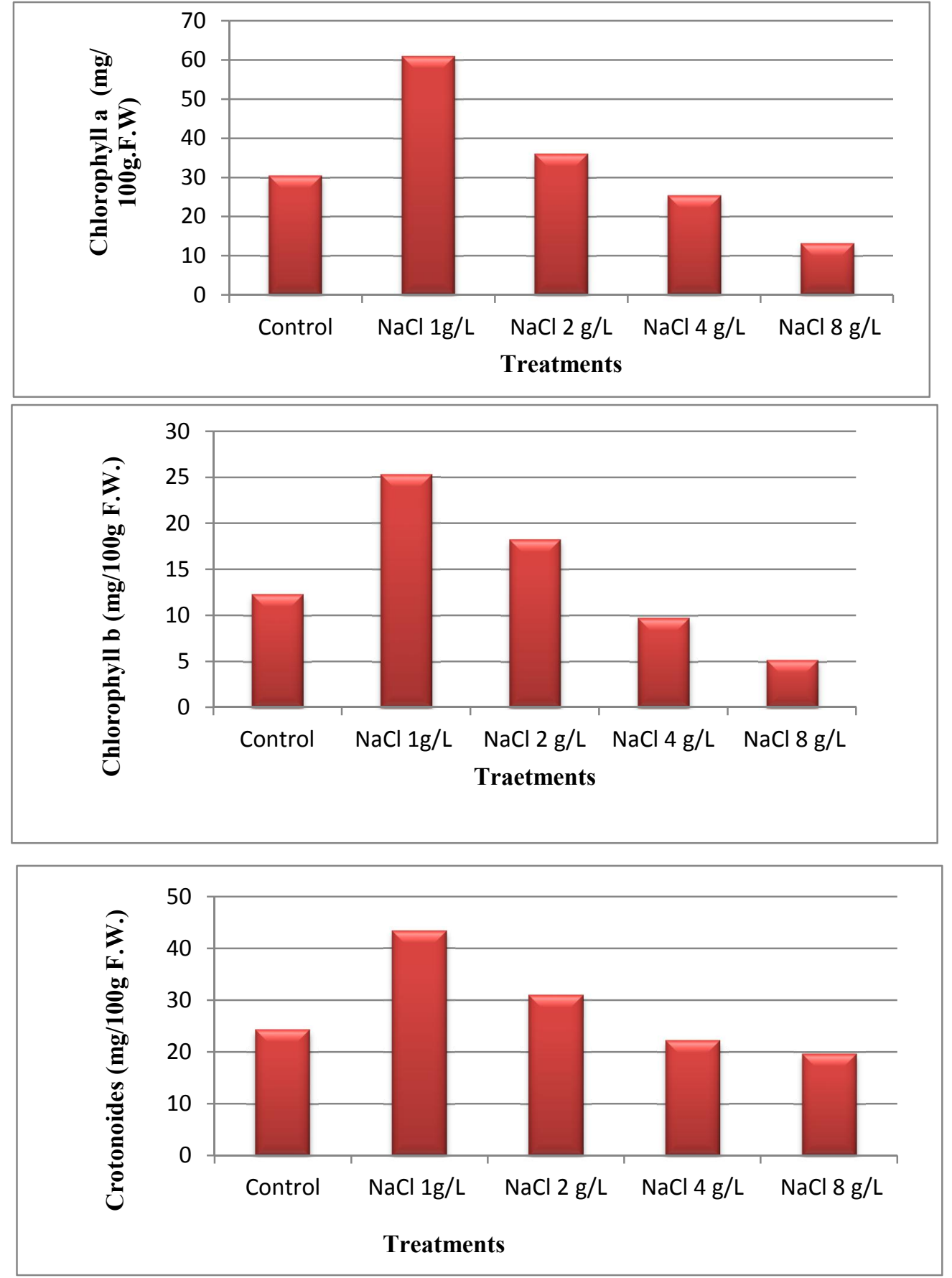

Fig. 5 (A, B and C): Effect of salt stress on Chlorophylls (a, b) and total carotenoids contents of Moringa olifera

\section{5- Effect of salt stress and iron oxide NPs on micropropagation ability}

In the present study, the effects of salinity and iron oxide NPs at various concentrations on in vitro growth ability were presented in Table (3) mentioned that, the iron oxide NPs decreased the effect of salt stress on in vitro growth of Moringa plants. The data showed that, using iron oxide NPs at $10 \mathrm{mg} / 1$ with $\mathrm{NaCl}$ at $1 \mathrm{~g} / \mathrm{L}$ gave the best results such as the highest survival percent $(100 \%)$,number of shootlets /explant (10.62), shootlet length $(46.07 \mathrm{~mm})$, and root percentage $(66.66 \%)$,root number (4.89)and root length $(21.62 \mathrm{~mm})$ as compared to other treatments and used $\mathrm{NaCl}$ only without iron oxide NPs. Moreover, using iron NPs at $5.0 \mathrm{~g} / \mathrm{L}$ or $10 \mathrm{~g} / \mathrm{L}$ gave positive effect on induction of roots with high concentration of $\mathrm{NaCl}(8 \mathrm{~g} / \mathrm{l})$ comparing with using $\mathrm{NaCl}$ alone. In finely, it can notice that iron oxide NPs promote root initiation under salinity stress in the current study on Moringa oliferera L. 
These results were in agreement with Ozturk et al. (2004) on lemon balm (Melissa officialis L.) who observed that iron NPs can decrease the effect of salinity in plants.

Soliman et al. (2015) on Moringa peregrine found that spraying plants with iron NPs increased growth parameters under salt stress.

Nano- technology can offer opportunities to enhance yield and counter environmental stress by using NPs (Anonymous, 2009).The application of NPs to plants can be beneficial (seedling growth and development) or non-beneficial (prevent root growth) (Zhu et al., 2008)

Table 3: In vitro shooting and rooting behaviors of Moringa olifera under effect of salt stress levels and iron oxide NPs.

\begin{tabular}{|c|c|c|c|c|c|c|}
\hline Characters & $\begin{array}{c}\text { Survival } \\
(\%)\end{array}$ & $\begin{array}{c}\text { No.of } \\
\text { shoolet/ } \\
\text { explant }\end{array}$ & $\begin{array}{c}\text { Shoot } \\
\text { Length } \\
(\mathrm{mm})\end{array}$ & $\begin{array}{c}\text { Rooting } \\
(\%)\end{array}$ & $\begin{array}{l}\begin{array}{l}\text { Number } \\
\text { of roots/ } \\
\text { shootlet }\end{array} \\
\end{array}$ & $\begin{array}{r}\text { Root } \\
\text { length } \\
(\mathrm{mm}) \\
\end{array}$ \\
\hline Control & $100.0 \mathrm{a}$ & $14.6 \mathrm{a}$ & $41.8 \mathrm{bc}$ & $66.6 \mathrm{a}$ & $5.0 \mathrm{a}$ & $29.3 \mathrm{a}$ \\
\hline $\mathrm{NaCl} 1 \mathrm{~g} / \mathrm{L}+5.0 \mathrm{mg} / \mathrm{L} \mathrm{Fe} \mathrm{NPs}$ & $100.0 \mathrm{a}$ & $10.0 \mathrm{~b}$ & $45.8 \mathrm{a}$ & $66.6 \mathrm{a}$ & $4.3 \mathrm{a}$ & $18.2 \mathrm{c}$ \\
\hline $\mathrm{NaCl} 1 \mathrm{~g} / \mathrm{L}+10 \mathrm{mg} / \mathrm{L} \mathrm{Fe} N P s$ & $100.0 \mathrm{a}$ & $10.6 \mathrm{~b}$ & $46.0 \mathrm{a}$ & $66.6 \mathrm{a}$ & $4.8 \mathrm{a}$ & $21.6 \mathrm{~b}$ \\
\hline $\mathrm{NaCl} 2 \mathrm{~g} / \mathrm{L}+5.0 \mathrm{mg} / \mathrm{L} \mathrm{Fe} \mathrm{NPs}$ & $100.0 \mathrm{a}$ & $8.0 \mathrm{bcd}$ & $44.1 \mathrm{ab}$ & $55.5 \mathrm{~b}$ & $4.0 \mathrm{a}$ & $15.2 \mathrm{~d}$ \\
\hline $\mathrm{NaCl} 2 \mathrm{~g} / \mathrm{L}+10 \mathrm{mg} / \mathrm{L} \mathrm{Fe} N P s$ & $100.0 \mathrm{a}$ & $9.0 \mathrm{bc}$ & $42.8 \mathrm{bc}$ & $55.5 \mathrm{~b}$ & $3.8 \mathrm{ab}$ & $14.0 \mathrm{~d}$ \\
\hline $\mathrm{NaCl} 4 \mathrm{~g} / \mathrm{L}+5.0 \mathrm{mg} / \mathrm{L} \mathrm{Fe} \mathrm{NPs}$ & $100.0 \mathrm{a}$ & $6.0 \mathrm{de}$ & $41.3 \mathrm{c}$ & $44.4 \mathrm{c}$ & $2.6 \mathrm{bc}$ & $12.4 \mathrm{e}$ \\
\hline $\mathrm{NaCl} 4 \mathrm{~g} / \mathrm{L}+10 \mathrm{mg} / \mathrm{L} \mathrm{Fe} \mathrm{NPs}$ & $100.0 \mathrm{a}$ & $7.0 \mathrm{~cd}$ & $38.8 \mathrm{~d}$ & $44.4 \mathrm{c}$ & $2.3 \mathrm{~cd}$ & $12.0 \mathrm{e}$ \\
\hline $\mathrm{NaCl} 8 \mathrm{~g} / \mathrm{L}+5.0 \mathrm{mg} / \mathrm{L} \mathrm{Fe} \mathrm{NPs}$ & $88.8 \mathrm{~b}$ & $4.5 \mathrm{e}$ & $38.5 \mathrm{~d}$ & $33.3 \mathrm{~d}$ & $1.3 \mathrm{de}$ & $6.9 \mathrm{f}$ \\
\hline $\mathrm{NaCl} 8 \mathrm{~g} / \mathrm{L}+10 \mathrm{mg} / \mathrm{L} \mathrm{Fe} \mathrm{NPs}$ & $77.7 \mathrm{c}$ & $5.0 \mathrm{e}$ & $36.0 \mathrm{e}$ & $33.3 \mathrm{~d}$ & $1.0 \mathrm{e}$ & $5.3 \mathrm{~g}$ \\
\hline
\end{tabular}

\section{6- Effect of salt stress and iron oxide NPs on proline content}

In this present, the data in Fig. 6 mentioned that, the proline content was increased gradually with increasing $\mathrm{NaCl}$ concentrations. The plants which were treated by $1 \mathrm{~g} / \mathrm{L}$ in culture media gave the lowest content of proline $(0.26 \mathrm{mg} / \mathrm{g} \mathrm{F}$.W.), but the plants that were treated by $8 \mathrm{~g} / \mathrm{L}$ gave the highest value of proline (2.24 mg/g F.W.).

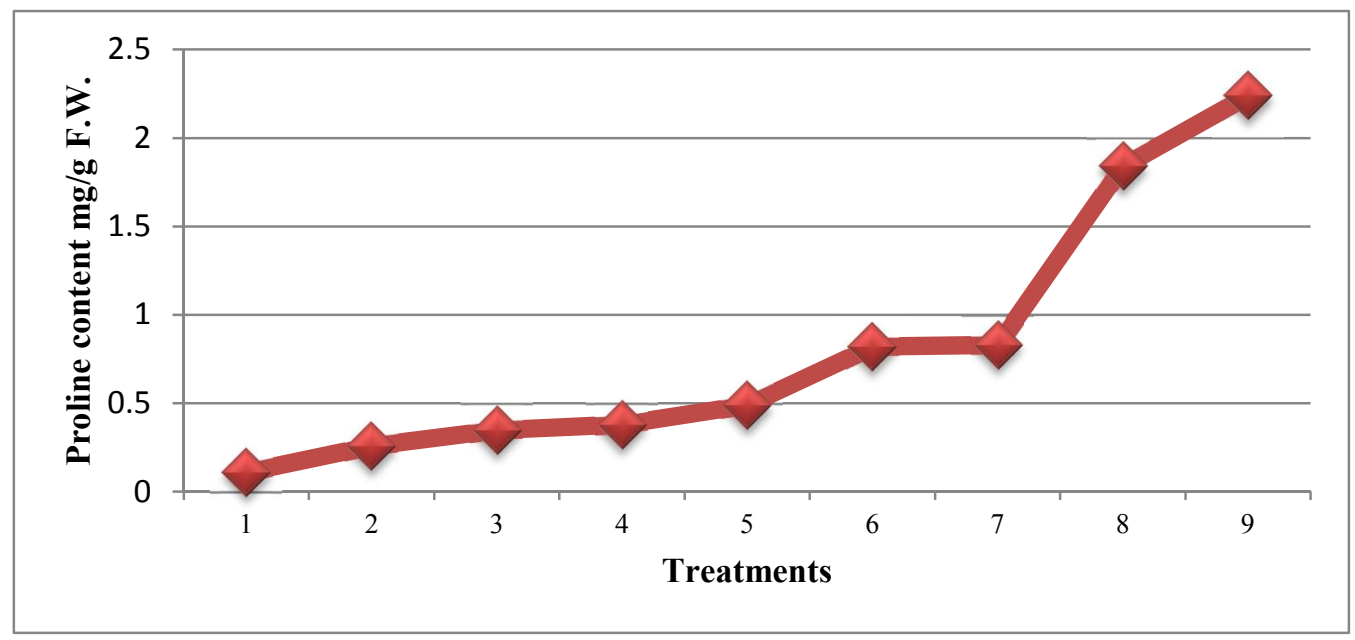

Fig. 6: In vitro proline content of Moringa olifera plant under effect of various concentrations of $\mathrm{NaCl}$ and iron oxide NPs.

1 (Control), 2 (Control+ NaCl (1 g/L) +5.0 mg/L Fe NPs), 3 (Control+ NaCl $(1 \mathrm{~g} / \mathrm{L})+10 \mathrm{mg} / \mathrm{L} \mathrm{Fe} \mathrm{NPs}), 4$ (Control+ NaCl (2 g/L) $+5.0 \mathrm{mg} / \mathrm{L} \mathrm{Fe} \mathrm{NPs}), 5$ (Control+ NaCl $(2 \mathrm{~g} / \mathrm{L})+5.0 \mathrm{mg} / \mathrm{L} \mathrm{Fe} \mathrm{NPs}), 6$ (Control+ $\mathrm{NaCl}(4$ $\mathrm{g} / \mathrm{L})+5.0 \mathrm{mg} / \mathrm{L} \mathrm{Fe} \mathrm{NPs}), 7$ (Control $+\mathrm{NaCl}(4 \mathrm{~g} / \mathrm{L})+10 \mathrm{mg} / \mathrm{L} \mathrm{Fe} \mathrm{NPs}), 8$ (Control+ NaCl $(4 \mathrm{~g} / \mathrm{L})+10 \mathrm{mg} / \mathrm{L} \mathrm{Fe}$ $\mathrm{NPs}), 9$ (Control+ $\mathrm{NaCl}(4 \mathrm{~g} / \mathrm{L})+10 \mathrm{mg} / \mathrm{L}$ Fe NPs)

The application of iron oxide NPs $(5.0$ and $10 \mathrm{mg} / \mathrm{L})$ gave a positive effect on salt stress with most concentrations of $\mathrm{NaCl}$. Application $10 \mathrm{mg} / \mathrm{L}$ iron oxide NPs was more effective than $5 \mathrm{mg} / \mathrm{L}$. plants treated by $8 \mathrm{~g} / \mathrm{L} \mathrm{NaCl}$ with $10 \mathrm{mg} / \mathrm{L}$ iron oxide NPs in culture media gave the highest proline content (2.24 mg/g F.W.). Meanwhile, plants treated with $8 \mathrm{~g} / \mathrm{L} \mathrm{NaCl}$ with $5.0 \mathrm{mg} / \mathrm{L}$ iron oxide NPs gave proline less than plants treated by $8 \mathrm{~g} / \mathrm{L} \mathrm{NaCl}$ with $10 \mathrm{mg} / \mathrm{L}$ iron oxide NPs. Using iron oxide NPs in culture medium increased proline more than using $\mathrm{NaCl}$ alone. 
The positive effect of appropriate $\mathrm{Fe}$ NPs concentrations on plant under $\mathrm{NaCl}$ stress could be explained by the replacement of Fe with Nano forms (Wang et al., 2011).

\section{7- Effect of salt stress and iron oxide NPs on Chlorophylls (a, b) and total carotenoids content.}

Indicated the influence of $\mathrm{NaCl}$ and iron oxide NPs at various concentrations was shown in Fig.(7) showed that treating Moringa olifera explant with $\mathrm{NaCl1.0} \mathrm{g/} \mathrm{and} 5.0 \mathrm{mg} / \mathrm{L} \mathrm{Fe} \mathrm{NPs} \mathrm{increased}$ total chlorophyll $(\mathrm{a}$ and $\mathrm{b})$ and carotenoids content to the highest values $(91.37,38.45$ and 66.15 $\mathrm{mg} / \mathrm{g} . \mathrm{F} . \mathrm{W}$ ) as compared to using $\mathrm{NaCl}$ only. While, using $\mathrm{NaCl} 8.0 \mathrm{~g} / \mathrm{L}$ and $10 \mathrm{mg} / \mathrm{Fe} \mathrm{NPs}$ declined this value and significantly reduced total chlorophyll ( $a$ and $b$ ) and carotenoids content as compared to control and other treatments. It can be noticed that using iron oxide NPs enhanced chlorophyll and carotenoids content under salinity stress as compared to use $\mathrm{NaCl}$ only.
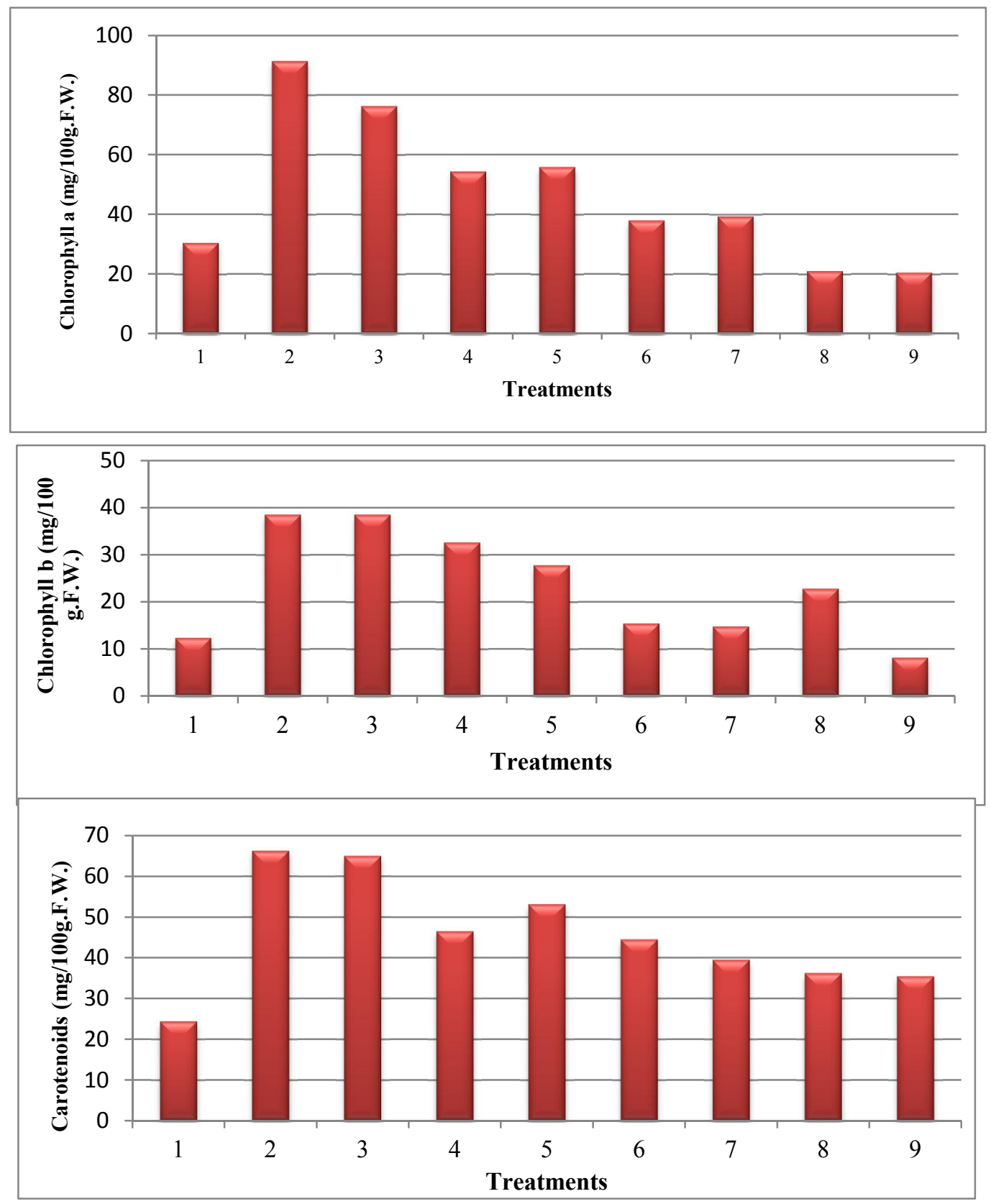

Fig. 7: Effect of salt stress and iron oxide Nano -practicalon Chlorophylls (a,b) and total carotenoids content.

1 (Control), 2 (Control+ NaCl (1 g/L) +5.0 mg/L Fe NPs), 3 (Control+ NaCl $(1 \mathrm{~g} / \mathrm{L})+10 \mathrm{mg} / \mathrm{L} \mathrm{Fe} \mathrm{NPs}), 4$ (Control+ NaCl (2 g/L) $+5.0 \mathrm{mg} / \mathrm{L} \mathrm{Fe} \mathrm{NPs),} 5$ (Control+ NaCl (2 g/L) +5.0 mg/L Fe NPs), 6 (Control+ NaCl (4 $\mathrm{g} / \mathrm{L})+5.0 \mathrm{mg} / \mathrm{L} \mathrm{Fe} \mathrm{NPs}), 7$ (Control+ NaCl $(4 \mathrm{~g} / \mathrm{L})+10 \mathrm{mg} / \mathrm{L} \mathrm{Fe} \mathrm{NPs}), 8$ (Control+ NaCl $(4 \mathrm{~g} / \mathrm{L})+10 \mathrm{mg} / \mathrm{L} \mathrm{Fe}$ $\mathrm{NPs}), 9$ (Control $+\mathrm{NaCl}(4 \mathrm{~g} / \mathrm{L})+10 \mathrm{mg} / \mathrm{L}$ Fe NPs) 


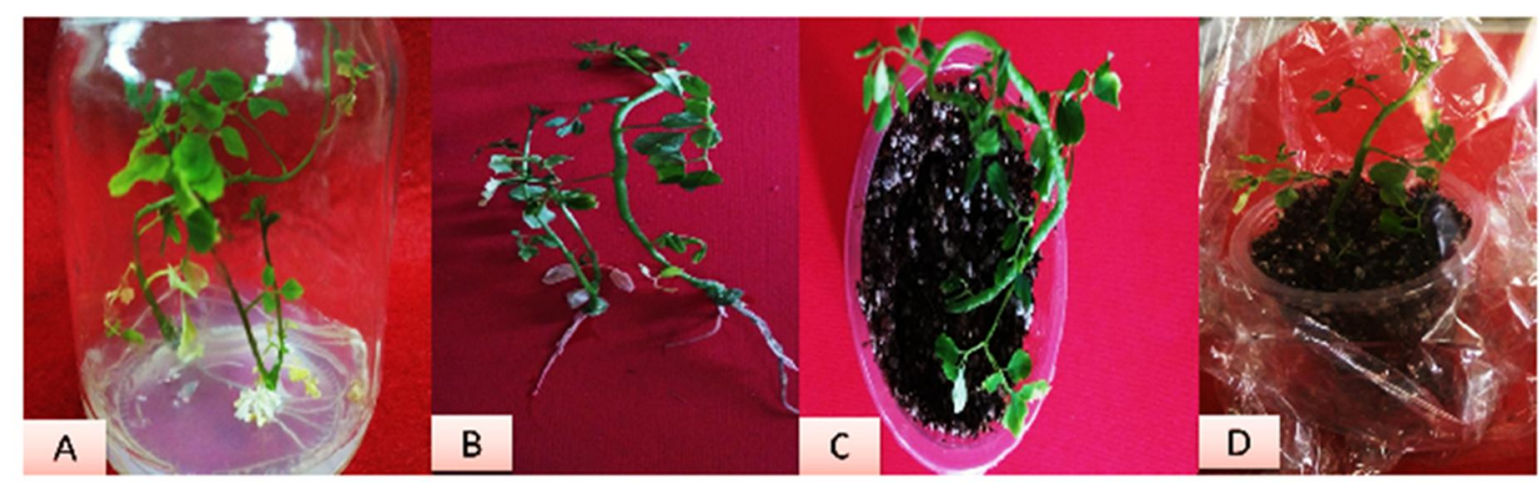

Fig. 8: In vitro shooting and rooting ability of Moringa olifera: (A): cultures on $1 \mathrm{~g} / \mathrm{LNaCl}+10 \mathrm{mg} / \mathrm{L}$ Fe NPs, (B): prepared rooted plantles for the acclumization stage and (C, D): Acclimatization to greenhouse.

These results are in agreement with the findings of Liu et al. (2005) who concluded that iron oxide NPs facilitated photosynthesis and iron transfer to leaves of peanut when compared to organic materials and iron citrate.

Iron also activates several enzymes and contributes in RNA synthesis and improves the performance of photosystems (Malakouti and Tehrani, 2005). In addition iron oxide NPs have been reported as facilitators for iron and photosynthetic transfer to the leaves of peanut (Liu et al., 2005).

\section{Conclusion}

In this study, the results showed that Moringa plants could overcome the effect of salt stress by using iron oxide NPs. The ability of in vitro shooting and rooting and chemical composition was increased by using iron oxide NPs under salt stress.

\section{Acknowledgement}

The authors of this work are greatly thankful to National Research Centre, 33 El Bohouth St., (formal El Tahrir St.), Dokki, Giza, Egypt, P.O.12622, for research facilities.

\section{References}

Anonymous, 2009. Nano technology in agriculture. J. Agric. Technol. 114:54-65.

Bates, L., R.P. Waldren, and I.D. Teare, 1973. Rapid determination of free proline for water-stress studies. Plant Soil, 39, 205-207.

Birendra, K. P., H. Kumar, J. Dhongade and B. Gidwani, 2017.Phytochemistry and Pharmacology of Moringa oleifera Lam. Journal of Pharmacopuncture, 20(3):194-200.

Chen, T.H. and N. Murata, 2000. Enhancement of tolerance of abiotic stress by metabolic engineering of betaines and other compatible solutes. Plant Biol. 5:250-257.

El-Fouly, M.M, Z.M. Mobarak and Z.A. Salama, 2002. Micronutrient foliar application increases salt tolerance of tomato seedlings. Proceedings of the Symposium on Techniques to Control Salination for Horticultural Productivity. Acta Hort. 573:377-385.

Gayathri, M., P.S. Kumar, A.M.L. Prabha, and G. Muralitharan, 2015. In vitro regeneration of Arachis hypogaea L. and Moringa oleifera Lam. using extracellular phytohormones from Aphanothece sp. MBDU 515.Alg Res, 7: 100-105.

Hairmansis, A., B. Berger, M. Tester and J.S. Roy, 2014.Image-based phenotyping for nondestructive screening of different salinity tolerance traits in rice. Rice 6:17.

Kao, W.Y., T.T. Tsai and C.N. Shih, 2003. Photosynthetic gas exchange and chlorophyll a fluorescence of three wild soybean species in response to $\mathrm{NaCl}$ treatments. Photosynthetica 41:415-419.

Khor, K. Z., V. Lim, E. J. Moses, and N. Abdul Samad, 2018. The In vitro and In vivo Anticancer Properties of Moringa oleifera. Evidence-Based Complementary and Alternative Medicine. Volume 2018, Article ID 1071243, 14 pages. 
Liu, X.M, F.D. Zhang, S.Q. Zhang, X.S. He, R. Fang, Z., Feng, and Y. Wang, 2005.Effects of nanoferric oxide on the growth and nutrients absorption of peanut. Plant Nutr. Fert. Sci., 11:14-18.

Malakouti, M. and M. Tehrani, 2005. Micronutrient role in increasing yield and improving the quality of agricultural products.1st ed. Tarbiat Modarres University in T.ehran press. Page 230 (in Persian).

Marfori, E.C., 2010. Clonal micropropagation of Moringa oleifera L. Philipp Agric Sci., 93: 454-457.

Mazaherinia, S., A. Astaraei, A. Fotovvat, A. Monshi, 2010.The comparison of iron absorption and accumulation in wheat by the application of common iron oxides and nano-oxides along with compost and granulated sulfur. Iranian J. Agron., 92: 103-111.

Munns, R., R.A. James and A. Läuchli, 2006. Approaches to increasing the salt tolerance of wheat and other cereals. Exp. Bot., 57(5):1025-43.

Murashige, T. and F. Skoog, 1962. A revised medium for rapid growth and bioassays with tobacco tissue cultures. Bilogia Plantarum, 15: 473-497.

Nayak, S., B. Hatwar, A. Jain, 2010 Effect of Cytokinin and Auxins on Meristem Culture of Bambusa arundinacea .Scholars Research Library. 2 (1) 408-414

Nontaswatsri, C., S. Fukai, T. Touma, and M. Goi, 2002. Comparison of adventitious shoot formation from node and leaf explants of various carnation (Dianthus caryophyllus L.) cultivars. J. Hortic. Sci. Biotechnol., 77, 520-525.

Ozturk A., A. Unlukara, A. Ipek, B. Gurbuz, 2004. Effects of salt stress and water deficit on plant growth and essential oil content of lemon balm (Melissa officialis L.). Pak. J. Bot. 36: 787792.

Park, H.J., H.R. Lee, J. Pyee and H.C. Cha, 2001. Regeneration of grape (Vitis labruscana cv. Kyoho) by shoot-tip culture. J. Plant Biol., 44, 185-192.

Rashno, M.H., Z.A. Tahmasebi Sarvestani, H. Heidari Sharifabad, S.A.M. Modarres Sanavi, R. Tavakkol Afshari . 2013. The effect of drought stress and iron spraying on yield and quality of two alfalfa cultivars. Iranian J. Crop Plants Prod., 1: 125-148.

Saini, R.K., N.P. Shetty, P. Giridhar, G.A. Ravishankar, 2012. Rapid in vitro regeneration method for Moringa oleifera and performance evaluation of field grown nutritionally enriched tissue cultured plants. Biotech, 2: 187-192.

Salem, J. M., 2016. In vitro Propagation of Moringa oleifera L. under Salinity and Ventilation Conditions. Genetics and Plant Physiolo Gy- 6(1-2), PP. 54-64.

Saric, M.R., T. Kastrori-Cupina, and I. Gergis, 1967. Chlorophyll determination Univ. Unoven SaduPrakitikum is KiziologizeBilika-Beagrad, Haucua Anjiga.; 215.

Sayed, A., H. Gul, Z. Ullah, M. Hamayun, 2014. Effect of Salt Stress on Growth of Tagetes erecta L.. Pakhtunkhwa J. Life Sci. Volume 02, P 96-106.

Soliman A.SH, N.T. Shanan, O.N. Massoud, D.M. Swelim, 2012.Improving salinity tolerance of Acacia saligna (Labill.) plant by arbuscularmycorrhizal fungi and Rhizobium inoculation. Afr. J. Biotechnol., 11(5):1259-1266.

Soliman, A., A. Souad El-feky and D. Essam, 2015. Alleviation of salt stress on Moringa peregrine using foliar application of nanofertilizers. Journal of Horticulture and Forestry, 7(2):36-47.

Stephenson, K.K. and J.W. Fahey, 2004. Development of tissue culture methods for the rescue and propagation of endangered Moringa spp. germplasm. Econ Bot., 58: 116-124.

Wang, H., X. Kou, Z. Pei, J.Q. Xiao, X. Shan, and B. Xing, 2011. Physiological effects of magnetite ( $\mathrm{Fe} 3 \mathrm{O} 4)$ nanoparticles on perennial ryegrass (Lolium perenne L.) and pumpkin (Cucurbita mixta) plants, Nanotoxicology 5(1):30-42.

Zhu, H., J. Han, J.Q. Xiao, and Y. Jin, 2008. Uptake, translocation and accumulation of manufactured iron oxide nanoparticles by pumpkin plants, J. Environ. Monitor. 10:713-717. 